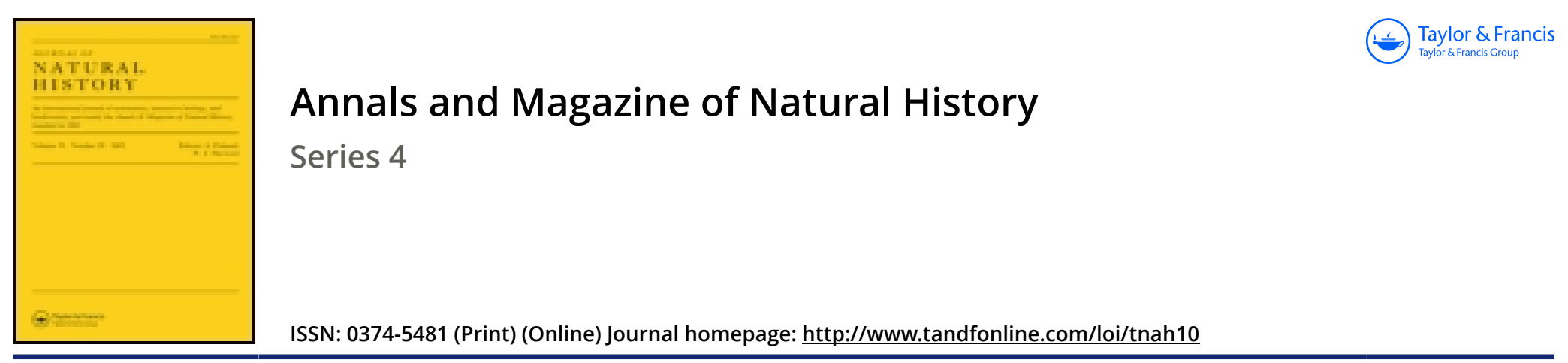

\title{
On a new class of Echinodermata
}

\section{Semper}

To cite this article: C. Semper (1868) On a new class of Echinodermata, Annals and Magazine of Natural History, 2:10, 316-317, DOI: $10.1080 / 00222936808695807$

To link to this article: http://dx.doi.org/10.1080/00222936808695807

$$
\text { 册 Published online: } 16 \text { Oct } 2009 .
$$

Submit your article to this journal

LII Article views: 4

Q View related articles $\asymp$ 
Obs. The Shetland Nudibranchs and Cephalopods have not been sufficiently investigated. Lovén's 'Index ' and a further list of Swedish Nudibranchs which he lately sent me contain 60 species of that order, out of which 22 only have been identified as Zetlandic. He also gives 9 species of Cephalopods, of which 3 only are Zetlandic. The southern distribution of our Nudibranchs is very little known. For the preparation of the present list of Nudibranchs I am in a great measure indebted to the late Mr. Alder and to Mr. Norman. Forty-five species of mollusca (marked $\dagger$ ) have been discovered in the Shetland seas since the publication of Forbes \& Hanley's 'History of British Mollusca and their Shells.'

\section{MISCELLANEOUS. \\ On a new Class of Echinodermuta. \\ By C. SeMrer.}

M. SEMPER has made an anatomical investigation of the genus Rhopalodina of Gray, which has led him to rather remarkable results. The animal had been classed by Dr. Gray, because of the form of its body, among the Holothuriæ. This body is formed of an anterior part having the form of a cylindrical peduncle, and of a spherical posterior part or abdomen. In this hinder region, at the point opposed to the insertion of the peduncle, are seen ten ambulacra, to which correspond in the interior, as in the Holothuriæ, ten radiating muscles, ten aquiferous canals with their ampullæ, and ten nerves. These ten rays of the abdomen, moreover, are prolonged into the peduncle, but without bearing any feet.

At the free extremity of the peduncle are the mouth and the anus, side by side. The margin of the mouth is entire; that of the anus is formed by a circle of ten papillæ. The tentacular crown of the pharynx is formed of ten pennated tentacles, which, in the two individuals studied by M. Semper, were hidden in the buccal eavity. The pharynx and the terminal part of the intestine consequently pass side by side in the interior of the peduncle. At the point where the peduncle enlarges to form the spherical abdomen, the anal intestine bears four long cæca. like the lungs of the Holothuriæ. At the corresponding point of the pharynx, between that organ and the intestine, appears a little swelling, serving as the point of attachment of a crowd of little blind tubes. These are the generative organs, constructed on the type of those of the Holothuriæ. The stomach forms in the abdomen a spiral with numerous turns and a double loop.

Of the ten rays above mentioned, five correspond with the pharynx and five with the intestine. The five radial muscles of the pharynx are attached, as in the Holothuriæ, to five radial pieces of the calcareous pharyngeal ring, which is formed of ten pieces in all. In this place there ought to exist a circular aquiferous vessel, as follows from the existence of two vesicles of Poli. Round the anus, 
immediately below the crown of anal papillæ, there is also a calcareous ring composed of ten pieces, of very regular form; and the five radiate muscles of the intestine are attached to the five radial pieces. The calcareous ring of the pharynx is placed a little deeper in the peduncle than that of the intestine; therefore a section of the peduncle at the level of the root of the buccal tentacles shows plainly the five radial muscles of the intestine, but not those of the pharynx. The small dimensions of the object have not, unfortus nately, allowed it to be ascertained how the aquiferous vessels of the rays behave in the neighbourhood of the calcareous rings. The existence of a double calcareous ring and the division of the rays into five intestinal and five pharyngeal rays might lead us to suppose that there exist two circular vessels. If, however, we admit, despite this arrangement, a single nervous ring and a single circular aquiferous vessel, it is still no less impossible to refer this singular animal to the typical form of the Holothuriæ, notwithstanding the incontestable affinities that have been indicated in the internal organs. We might, it is true, suppose the Rhopalodince to have resulted from a Psolus or Colochirus whose buccal and anal cones had been much elongated and soldered to one another; but although that transformation might produce a form analogous to Rhopalodina, the rays could not be arranged as in these animals. The two dorsal rays should, on the contrary, disappear entirely; and we ought to find on the peduncle two groups of three rays becoming continued one into the other at the extremity of the abdomen.

In all living Echinoderms the anus is placed either opposite to the mouth in the centre of the radiate arrangement or in an interradium. In some fossil Crinoids alone (the Crinoidea tessellata) there exist more than five rays placed round a single central aperture. These are in reality the only Echinoderms in which we could suppose an arrangement of the pharynx and intestine in relation to the rays like that which M. Semper has described in Rhopalodina. Yet these latter could not be united with the Crinoids, because of the totally different structure of their ambulacra, leaving out of consideration that their internal organs approximate them much more to the Holothuriæ.

The author does not see any other way of getting out of the difficulty than to create for these singular animals a new class, under the name of Echinodermes diplostomes. He promises us a detailed description of the genus Rhopalodina in a supplement to his great work on the Holothuriæ. - Verhandl. phys.-med. Gesellsch. in Würzburg, June 6, 1868: Bibl. Unï. August 15, 1868, Bull. Sci. pp. 326-328.

\section{Coccoliths and Coccospheres. By G. C. WaLLICH.}

September 7, 1868.

In a lecture " On a Piece of Chalk," delivered by Prof. Huxley to working men during the recent meeting of the British Association, and published with the author's initials in the September number of Ann. \& Mag. N. Hist. Ser. 4. Vol. ii. 